\title{
The results of clinical trial on immunogenicity of adjuvanted quadrivalent inactivated subunit influenza vaccine Grippol Quadrivalent in pediatric population 6 to 17 years old
}

\author{
O.P. Kovtun ${ }^{1}$, V.V. Romanenko ${ }^{1}, I . V$. Feldblum $^{2}, A . U$. Sabitov$^{1}$, and A.V. Ankudinova ${ }^{1,3, *}$ \\ ${ }^{1}$ Ural State Medical University, 620014, Yekaterinburg, Russian Federation \\ 2.Perm State Medical University, 614000, Perm, Russian Federation \\ 3. Yekaterinburg Medical Research Center for Prophylaxis and Health Protection in Industrial \\ Workers, Russian Agency for Consumer Rights Protection 'Rospotrebnadzor', 620014 \\ Yekaterinburg, Russian Federation
}

\begin{abstract}
Russian health care workers currently use trivalent influenza vaccines with a strain of a single lineage of type B virus. The purpose of our study was to evaluate the immunogenicity of an adjuvanted quadrivalent inactivated subunit influenza vaccine Grippol Quadrivalent in pediatric population 6 to 17 years old. We compared this new vaccine to a trivalent Grippol Plus vaccine in terms of immunogenicity against certain strains of influenza virus. A multicenter double-blind randomized controlled clinical study was conducted in 440 pediatric subjects (age groups: 6 to $11 ; 12$ to 17 y.o.); 221 subjects received Grippol Quadrivalent, 219 - Grippol Plus. Vaccine immunogenicity was evaluated by seroprotection rate (SPR), seroconversion rate (SCR), geometric mean titer (GMT) of antibodies, and an X-fold rise in antibodies level ( $\uparrow$ GMT). Antibodies quantification was done using hemagglutination inhibition assay (HAI) in serial serum dilutions. No significant differences were found between the two vaccines' performance against $\mathrm{A}\left(\mathrm{H}_{1} \mathrm{~N}_{1}\right), \mathrm{A}\left(\mathrm{H}_{3} \mathrm{~N}_{2}\right)$ strains or Victoria $\mathrm{B}$ virus. With respect to type A virus, both vaccines satisfied three of CPMP criteria (SPR, SCR, $\uparrow$ GMT). With respect to Victoria $\mathrm{B}$ virus, the two vaccines met but one CPMP criterion ( $\uparrow$ GMT). The immunogenicity against Yamagata B virus was evaluated only for Grippol Quadrivalent vaccine which met two of CPMP requirements (SCR, $\uparrow \mathrm{GMT}$ ). Our findings suggest that in terms of its prophylactic efficiency, Grippol Quadrivalent vaccine is no inferior to the Grippol Plus one.
\end{abstract}

\section{Introduction}

The prevention of seasonal influenza remains one of the global health care priorities due to the high transmission rates of the disease $[1,2,3,4]$. Children are three times more likely to

\footnotetext{
* Corresponding author: doctorankudinova2007@gmail.com
} 
get sick $[5,6]$. The outbreaks of seasonal flu result in huge socio-economic losses every year $[1,7,8]$.

As confirmed with numerous studies, vaccination is the most effective strategy in dealing with influenza infection, preventing complications and virus-related deaths $[5,6,9$, 10]. In 1976 WHO published its first guidelines on strain composition of influenza vaccines; since then these recommendations are revisited every year to meet high evolutionary variability of influenza viruses [11].

As suggested by international surveys, up to the late 1970s, the antigen structure of then-circulating type B virus remained conservative; since the mid-1980s there come two different antigen strains of type B virus which co-existed with other types of influenza viruses at the time. In 2011, Victoria lineage of type B virus was responsible for about $60 \%$ of all influenza cases. Therefore, a single-lineage type B vaccine wasn't providing a full coverage which resulted in a decreased protective immunity among the vaccinated population. First quadrivalent vaccines containing the strains of both B virus lineages Victoria and Yamagata - arrived at 2013. As of now, there are six companies out there currently manufacturing quadrivalent vaccines [12].

Our purpose was to evaluate the immunogenicity of a Russian adjuvanted quadrivalent inactivated subunit influenza vaccine Grippol Quadrivalent in pediatric population 6 to 17 years old; and to compare its immunogenicity to that of a trivalent Grippol Plus vaccine.

\section{Materials and methods}

A multicenter double-blind randomized controlled clinical trial of vaccines containing relevant strains was conducted during the 2017-2018 and 2018-2019 seasonal outbreaks of influenza infection. Six Russian research institutions located in Moscow, Saint Petersburg (two centers), Perm, Yekaterinburg and Barnaul took part in the study.

The criteria of inclusion: pediatric population of both sexes with no known health issues, age 6 to 17 at the time of vaccination. All research participants age 14-17 signed an informed consent; for younger kids, the consent was given and signed by one parent.

The criteria of exclusion: a refusal to continue participation in the trial articulated by a parent or a subject age 14-17.

After a randomization procedure, 440 participants received vaccination (218 subjects age 6-11; 222 subjects age 12-17). 221 participants (109 subjects age 6-11; 112 subjects age 12-17) were randomly assigned to Grippol Quadrivalent subgroup and 219 participants (109 subjects age 6-11; 110 subjects age 12-17) went to Grippol Plus subgroup. One kid $(0.2 \%)$ left the trial. Except for that, everyone finished the trial in compliance with the protocol. No serious departure from the protocol was registered.

Vaccine was administered via a single intramuscular injection of $0.5 \mathrm{ml}$ of the vaccine preparation (Grippol Quadrivalent or Grippol Plus) to the deltoid muscle site of the upper arm.

Both vaccines preparations were colorless or yellowish opalescent solutions and contained no conserving agent. Grippol Quadrivalent vaccine solution was prepared of:

$\mathrm{A}\left(\mathrm{H}_{1} \mathrm{~N}_{1}\right)$ virus antigen, $5 \mu \mathrm{g}$

$\mathrm{A}\left(\mathrm{H}_{3} \mathrm{~N}_{2}\right)$ virus antigen, $5 \mu \mathrm{g}$

Victoria B virus antigen, $5 \mu \mathrm{g}$

Yamagata B virus antigen, $5 \mu \mathrm{g}$

Immune adjuvant Polyoxydonium, $500 \mu \mathrm{g}$

Phosphate buffered saline (PBS) - up to $0.5 \mathrm{ml}$ 
The reference preparation of Grippol Plus vaccine contained all the same components except for Yamagata B virus antigen.

Blood sample for immunogenicity assessment was collected during the screening procedure and on the $22-28^{\text {th }}$ day after the vaccination (a $3^{\text {rd }}$ visitation). Vaccine immunogenicity was evaluated by seroprotection, seroconversion, and a GMT dynamics of the strain-relevant antibodies level.

Immune efficiency assessment relied on the results of hemagglutination inhibition assay (HAI) conducted at the Smorodintsev Research Institute of Influenza (Saint Petersburg) according to the laboratory standard operational procedures. The laboratory personnel working with serum samples was blinded with respect to the information on both the results of the randomization and an actual vaccine administration to the participants.

The study was performed in compliance with the clinical trial protocol, ethical principles outlined in the Helsinki declaration (64th WMA General Assembly, Fortaleza, Brazil, October 2013), quality standards of Good Clinical Practice of the International Conference on Harmonisation (ICH GCP), and the legal requirements of the Russian Federation.

\section{Results and discussion}

In 6-11 age group vaccinated with Grippol Quadrivalent, seroconversion rates as measured on the $28^{\text {th }}$ day after the procedure were as follows: $45.0 \%$ (CI 95\%: 35.7-54.3) against $\mathrm{A}\left(\mathrm{H}_{1} \mathrm{~N}_{1}\right)$ strain, 66.1\% (CI 95\%: 57.2-75.0) against $\mathrm{A}\left(\mathrm{H}_{3} \mathrm{~N}_{2}\right)$ strain, $26.6 \%$ (CI 95\%: 18.334.9) against Victoria B strain, and 62.4\% (CI 95\%: 53.3-71.5) against Yamagata B strain, with GMT rates: 120.18 (CI 95\%: 93.02-155.27), 178.27 (CI 95\%: 144.80-219.47), 13.66 (CI 95\%: 11.37-16.41), and 31.61 (CI 95\%: 24.50-40.80), respectively. These results are no statistically different from those in the reference group vaccinated with Grippol Plus vaccine and meet the CPMP criteria for $\mathrm{A}\left(\mathrm{H}_{1} \mathrm{~N}_{1}\right), \mathrm{A}\left(\mathrm{H}_{3} \mathrm{~N}_{2}\right)$, and Victoria $B$ strains (Table 1) [14].

Table 1. Immunogenicity estimates in age groups 6-11 and 12-17

\begin{tabular}{|c|c|c|c|c|}
\hline & \multicolumn{2}{|c|}{ Grippol Quadrivalent, n=221 } & \multicolumn{2}{|c|}{ Grippol Plus, n=219 } \\
\hline & $\begin{array}{l}\text { Age } 6-11 \\
n=110\end{array}$ & $\begin{array}{l}\text { Age 12-17, } \\
\mathrm{n}=111\end{array}$ & $\begin{array}{c}\text { Age 6-11, } \\
n=110\end{array}$ & $\begin{array}{c}\text { Age 12-17 } \\
\mathrm{n}=109\end{array}$ \\
\hline \multicolumn{5}{|c|}{$\mathrm{A}\left(\mathrm{H}_{1} \mathrm{~N}_{1}\right)$} \\
\hline \multicolumn{5}{|c|}{ GMT of antibodies } \\
\hline $\begin{array}{c}\text { Before } \\
\text { vaccination }\end{array}$ & $\begin{array}{c}37.09 \\
\text { (CI 95\%: } \\
28.35-48.51)\end{array}$ & $\begin{array}{c}32.96 \\
\text { (CI 95\%: } \\
25.82-42.07)\end{array}$ & $\begin{array}{c}38.52 \\
\text { (CI 95\%: } \\
29.06-51.05)\end{array}$ & $\begin{array}{c}32.64 \\
\text { (CI 95\%: } \\
25.53-41, .72)\end{array}$ \\
\hline $22-28^{\text {th }}$ day & $\begin{array}{c}120.18 \\
\text { (CI 95\%: } \\
93.02-155.27)\end{array}$ & $\begin{array}{c}109.32 \\
\text { (CI 95\%: } \\
93.42-127.93)\end{array}$ & $\begin{array}{c}188.48 \\
\text { (CI 95\%: } \\
146.89-241.86)\end{array}$ & $\begin{array}{c}114.95 \\
\text { (CI 95\%: } \\
94.11-140.40)\end{array}$ \\
\hline \multicolumn{5}{|c|}{ Seroconversion } \\
\hline $22-28^{\text {th }}$ day & $\begin{array}{c}45.0 \\
\text { (CI 95\%: 35.7- } \\
54, .3)\end{array}$ & $\begin{array}{c}56.8 \\
\text { (CI 95\%: 47.6- } \\
66.0)\end{array}$ & $\begin{array}{c}62.7 \\
\text { (CI 95\%: } 53.7- \\
71.7)\end{array}$ & $\begin{array}{c}54.1 \\
\text { (CI 95\%: 44.7- } \\
63.5)\end{array}$ \\
\hline \multicolumn{5}{|c|}{ Seroprotection } \\
\hline
\end{tabular}




\begin{tabular}{|c|c|c|c|c|}
\hline $\begin{array}{c}\text { Before } \\
\text { vaccination }\end{array}$ & \multicolumn{2}{|c|}{$55.3 \%$ (CI 95\%: 48.4-62.0) } & \multicolumn{2}{|c|}{$55.3 \%$ (CI 95\%: 48.4-62.0) } \\
\hline $28^{\text {th }}$ day & \multicolumn{2}{|c|}{ 92.2\% (CI 95\%: 87.9-95.4) } & \multicolumn{2}{|c|}{$92.2 \%$ (CI 95\%: 87.9-95.4) } \\
\hline \multicolumn{5}{|c|}{$\mathrm{A}\left(\mathrm{H}_{3} \mathrm{~N}_{2}\right)$} \\
\hline \multicolumn{5}{|c|}{ GMT of antibodies } \\
\hline $\begin{array}{c}\text { Before } \\
\text { vaccination }\end{array}$ & $\begin{array}{c}40, .00 \\
\text { (CI 95\%: } \\
31.47-50.85)\end{array}$ & $\begin{array}{c}49.77 \\
\text { (CI 95\%: } \\
38.97-63.57)\end{array}$ & $\begin{array}{c}49.87 \\
\text { (CI 95\%: } \\
38.86-63.99)\end{array}$ & $\begin{array}{c}52.25 \\
\text { (CI 95\%: } \\
41.45-65.86)\end{array}$ \\
\hline $28^{\text {th }}$ day & $\begin{array}{c}178.27 \\
\text { (CI 95\%: } \\
\text { 144.80-219.47) }\end{array}$ & $\begin{array}{c}211.91 \\
\text { (CI 95\%: } \\
\text { 182.96-245.45) }\end{array}$ & $\begin{array}{c}179.22 \\
\text { (CI 95\%: } \\
148.90-215.70)\end{array}$ & $\begin{array}{c}184.03 \\
\text { (CI 95\%: } \\
158.39-213.81)\end{array}$ \\
\hline \multicolumn{5}{|c|}{ Seroconversion } \\
\hline $28^{\text {th }}$ day & $\begin{array}{c}66.1 \\
\text { (CI 95\%: } 57.2- \\
75.0)\end{array}$ & $\begin{array}{c}59.5 \\
\text { (CI 95\%: 50.4- } \\
68.6)\end{array}$ & $\begin{array}{c}53.6 \\
\text { (CI 95\%: 44.3- } \\
62.9)\end{array}$ & $\begin{array}{c}56.9 \\
\text { (CI 95\%: 47.6- } \\
66.2)\end{array}$ \\
\hline \multicolumn{5}{|c|}{ Seroprotection } \\
\hline $\begin{array}{c}\text { Before } \\
\text { vaccination }\end{array}$ & \multicolumn{2}{|c|}{$70.6 \%$ (CI 95\%: 64.1-76.5) } & \multicolumn{2}{|c|}{ 75.8\% (CI 95\%: 69.6-81.3) } \\
\hline $28^{\text {th }}$ day & \multicolumn{2}{|c|}{ 98.2\% (CI 95\%: 95.4-99.5) } & \multicolumn{2}{|c|}{ 97.7\% (CI 95\%: 94.8-99.3) } \\
\hline \multicolumn{5}{|c|}{ B type (Victoria lineage) } \\
\hline \multicolumn{5}{|c|}{ GMT of antibodies } \\
\hline $\begin{array}{c}\text { Before } \\
\text { vaccination }\end{array}$ & $\begin{array}{c}5.93 \\
\text { (CI 95\%: } 5.47- \\
6.43) \\
\end{array}$ & $\begin{array}{c}19.51 \\
\text { (CI 95\%: } \\
15.45-24.63) \\
\end{array}$ & $\begin{array}{c}5.57 \\
\text { (CI 95\%: 5.16- } \\
6.00) \\
\end{array}$ & $\begin{array}{c}20.52 \\
\text { (CI 95\%: } \\
16.09-26.15)\end{array}$ \\
\hline $28^{\text {th }}$ day & $\begin{array}{c}13.66 \\
\text { (CI 95\%: } \\
11.37-16.41) \\
\end{array}$ & $\begin{array}{c}50.40 \\
\text { (CI 95\%: } \\
40.14-63.28)\end{array}$ & $\begin{array}{c}14.59 \\
\text { (CI 95\%: } \\
11.82-18.02) \\
\end{array}$ & $\begin{array}{c}63.63 \\
\text { (CI 95\%: } \\
50.54-80.11)\end{array}$ \\
\hline \multicolumn{5}{|c|}{ Seroconversion } \\
\hline $28^{\text {th }}$ day & $\begin{array}{c}26.6 \\
\text { (CI 95\%: 18.3- } \\
34.9) \\
\end{array}$ & $\begin{array}{c}38.7 \\
\text { (CI 95\%: 29.6- } \\
47.8) \\
\end{array}$ & $\begin{array}{c}30.00 \\
\text { (CI 95\%: } 214- \\
386)\end{array}$ & $\begin{array}{c}468 \\
\text { (CI 95\%: 374- } \\
56.2)\end{array}$ \\
\hline \multicolumn{5}{|c|}{ Seroprotection } \\
\hline $\begin{array}{c}\text { Before } \\
\text { vaccination }\end{array}$ & \multicolumn{2}{|c|}{$20.4 \%$ (CI 95\%: 15.3-26.3) } & \multicolumn{2}{|c|}{$21.5 \%$ (CI 95\%: 16.2-27.5) } \\
\hline $28^{\text {th }}$ day & \multicolumn{2}{|c|}{$53.6 \%$ (CI 95\%: 46.8-60.4) } & \multicolumn{2}{|c|}{$56.2 \%$ (CI 95\%: 49.3-62.8) } \\
\hline \multicolumn{5}{|c|}{ B type (Yamagata lineage) } \\
\hline \multicolumn{5}{|c|}{ GMT of antibodies } \\
\hline $\begin{array}{c}\text { Before } \\
\text { vaccination }\end{array}$ & $\begin{array}{c}6.60 \\
\text { (CI 95\%: } 5.85- \\
7.44)\end{array}$ & $\begin{array}{c}9.81 \\
\text { (CI 95\%: 8.41- } \\
11.45)\end{array}$ & - & - \\
\hline $28^{\text {th }}$ day & $\begin{array}{c}31.61 \\
\text { (CI 95\%: } \\
24.50-40.80)\end{array}$ & $\begin{array}{c}25.52 \\
\text { (CI 95\%: } \\
21.30-30.56)\end{array}$ & - & - \\
\hline
\end{tabular}




\begin{tabular}{|c|c|c|c|c|}
\hline \multicolumn{5}{|c|}{ Seroconversion } \\
\hline $28^{\text {th }}$ day & $\begin{array}{c}62.4 \\
\text { (CI 95\%: } 53.3- \\
71.5)\end{array}$ & $\begin{array}{c}39.6 \\
\text { (CI 95\%: } 30.5- \\
48.7)\end{array}$ & - & - \\
\hline \multicolumn{5}{|c|}{ Seroprotection } \\
\hline $\begin{array}{c}\text { Before } \\
\text { vaccination }\end{array}$ & \multicolumn{2}{|c|}{$10.9 \%$ (CI 95\%: 7.1-15.7) } & \multicolumn{2}{|c|}{-} \\
\hline $28^{\text {th }}$ day & \multicolumn{2}{|c|}{$58.6 \%$ (CI 95\%: 51.8-65.2) } & \multicolumn{2}{|c|}{ - } \\
\hline
\end{tabular}

Low immunogenicity of Victoria B/Colorado strain in both vaccines can be explained partially by its specific features and also by no priming effect in the vaccinated population (a large majority of the participants showed initially low or zero levels of antibodies against this strain since it has no current circulation in Russia).

In 12-17 age group vaccinated with Grippol Quadrivalent, seroconversion rates as measured on the $28^{\text {th }}$ day after the procedure were as follows: $56.8 \%$ (CI 95\%: 47.6-66.0) against $\mathrm{A}\left(\mathrm{H}_{1} \mathrm{~N}_{1}\right)$ strain, 59.5\% (CI 95\%: 50.4-68.6) against $\mathrm{A}\left(\mathrm{H}_{3} \mathrm{~N}_{2}\right)$ strain, $38.7 \%$ (CI 95\%: 29.6-47.8) against Victoria B strain, and 39.6\% (CI 95\%: 30.5-48.7) against Yamagata B strain, with GMT numbers: 109.32 (CI 95\%: 93.42-127.93), 211.91 (CI 95\%: 182.96245.45), 50.40 (CI 95\%: 40.14-63.28), and 25.52 (CI 95\%: 21.30-30.56), respectively. These results are no statistically different from those in the reference group vaccinated with Grippol Plus vaccine and meet the CPMP criteria for $\mathrm{A}\left(\mathrm{H}_{1} \mathrm{~N}_{1}\right)$ and $\mathrm{A}\left(\mathrm{H}_{3} \mathrm{~N}_{2}\right)$ strains (Table 1) $[14]$.

We also studied such indicator of vaccine immunogenicity as a seroprotection rate. The estimation was done overall across both age groups on the $28^{\text {th }}$ day after the procedure. In Grippol Quadrivalent group, seroprotection rates were as follows: 93.62\% (CI 95\%: 90.3396.91) against $\mathrm{A}\left(\mathrm{H}_{1} \mathrm{~N}_{1}\right)$ strain, 98.31\% (CI 95\%: 96.47-100) against $\mathrm{A}\left(\mathrm{H}_{3} \mathrm{~N}_{2}\right)$ strain, 53.38\% (CI 95\%: 48.02-58.74) against Victoria B strain, and 59.19\% (CI 95\%: 53.2465.14) against Yamagata B strain. We run a Fisher test to compare the proportions of the subjects with seroprotection and found no statistically significant differences between the two groups (Grippol Quadrivalent and Grippol Plus) with respect to $\mathrm{A}(\mathrm{H} 1 \mathrm{~N} 1)(\mathrm{p}=0.582)$, $\mathrm{A}(\mathrm{H} 3 \mathrm{~N} 2)(\mathrm{p}=0.751)$, and Victoria $\mathrm{B}(\mathrm{p}=0.632)$ strains protection.

We compared the proportions of the subjects with seroconversion (SC+ subjects) as estimated on the $22-28^{\text {th }}$ day after the vaccination. The comparison was done with respect to the three strains common for both vaccines. We calculated the Wald intervals (CI 95.02\%) for differences between the proportions and applied an initial titer logarithmic correction. The upper estimates of the Wald CIs for $\mathrm{A}\left(\mathrm{H}_{3} \mathrm{~N}_{2}\right)$ and $\mathrm{B}$ (Victoria) strains didn't exceed the non-inferiority margin $0.15(15 \%)$. This statistics means that, with respect to these two strains, a new tested vaccine (Grippol Quadrivalent) is no inferior to the reference one (Grippol Plus). With respect to $\mathrm{A}\left(\mathrm{H}_{1} \mathrm{~N}_{1}\right)$ strain, the upper value of the $95.02 \%$ Wald $\mathrm{CI}$ for proportion difference was scarcely $(+0.0077)$ above the non-inferiority margin $0.15(15 \%)$. The confidence interval contained zero, which points to no statistically significant difference between the two groups.

With respect to seroconversion against $\mathrm{A}\left(\mathrm{H}_{1} \mathrm{~N}_{1}\right)$ strain, the upper estimate of the $95.02 \%$ Wald CI for proportion differences in the compared groups was above the non-inferiority margin of efficiency. Seroconversion in both groups satisfied the required CPMP rate [14]. The lower estimates of $95 \%$ CIs of the proportions of SC+ subjects laid to the right from the established $40 \%$ limit. Furthermore, with respect to $\mathrm{A}\left(\mathrm{H}_{1} \mathrm{~N}_{1}\right)$ strain, the studied groups evaluations met the CPMP criteria as defined for the adult population. There was a 2.5 -fold 
increase in the GMT of antibodies; the proportion of the subjects with seroprotection after vaccination was estimated above $70 \%$ [14].

In terms of the immune efficiency against $\mathrm{A}\left(\mathrm{H}_{3} \mathrm{~N}_{2}\right)$ strain, there was found no statistical differences between the two vaccines, and they both satisfied the CPMP requirements [14].

With regard to action against Victoria B strain, the vaccines did not differ, and they both failed to meet the CPMP requirements [14] for seroprotection and seroconversion rates. The lower estimates of $95 \%$ CIs of the proportions of SC+ subjects laid to the left of the established $40 \%$ limit. The lower estimates of $95 \%$ CIs of the proportions of SP+ subjects were to the left of the established $70 \%$ limit.

With respect to its action against Yamagata B strain, Grippol Quadrivalent vaccine met CPMP requirements for seroconversion and an X-fold GMT increase of antibodies after vaccination.

\section{Conclusions}

The obtained data suggest Grippol Quadrivalent vaccine to be of no less immunologic efficiency as compared to a trivalent Grippol Plus vaccine. The safety profile of the new quadrivalent vaccine is generally promising and compatible with that of the Grippol Plus.

The study was financed by OOO ‘NPO Petrovax Farm', Russia.

\section{References}

1. G.G. Onishchenko, E.B. Ezhlova, A.A. Melnikova, Pediatricheskaya farmakologiya, 10(2), 10-18 (2013)

2. A. Sominina, E. Burtseva, M. Eropkin et al., J. Infect. Dis., 9(3), 77-93 (2013)

3. A. G. Chuchalin, Guidelines on influenza in adults (2014)

4. N.A. Miromanova, A(H1N1) influenza pathogenesis in children (2015)

5. L.V. Semenova, Influenza epidemiology and vaccination (2012)

6. T.V. Chebykina, Influenza and acute respiratory infections in high risk population (2018)

7. O.S. Konshina, A.A. Sominina, E.A. Smorodintseva et al, Infektsiya i immunitet, 7(1), 27-33 (2017)

8. A. G. Chuchalin, Pulmonologiya, 5, 11-19 (2014)

9. S.M. Kharit, D.A. Lioznov, A.A. Ruleva et al., Epidemiologiya i vaktsinoprofilaktika, 2(93), 24-30 (2017)

10. WHO official website, URL: http://www.euro.who.int/ru/health-topics/communicablediseases/influenza/vaccination/influenza-vaccination-coverage-and-effectiveness

11. N.I. Brikoo, Epidemiologiya i vaktsinoprofilaktika, 17(4), 68-97 (2018)

12. WHO official website, URL: http://www.euro.who.int/ru/health-topics/communicablediseases/influenza/news/news/2019/3/who-releases-recommendations-for-the20192020-northern-hemisphere-seasonal-influenza-vaccine

13. European Centre for Disease Prevention and Control official website, URL: https://www.ecdc.europa.eu/en/publications-data/protocols-case-control-studiesmeasure-influenza-vaccine-effectiveness-eu-and-eea

14. Committee for Proprietary Medicinal Products, Note for guidance on harmonisation of requirements for influenza vaccines, CPMP/EWP/1045/01 (2001) 